\title{
Ebf2 Marks Early Cortical Neurogenesis and Regulates the Generation of Cajal-Retzius Neurons in the Developing Cerebral Cortex
}

\author{
Shu-Mien Chuanga,c Yue Wang ${ }^{c}$ Qingjie Wang ${ }^{c, d}$ Keh-Min Liu ${ }^{b}$ Qin Shen ${ }^{c-f}$ \\ ${ }^{a}$ Graduate Institute of Medicine, and ${ }^{b}$ Department of Anatomy, College of Medicine, Kaohsiung Medical University, \\ Kaohsiung, Taiwan, ROC; ' Neural Stem Cell Institute, Rensselaer, N.Y., and d Center for Neuropharmacology and

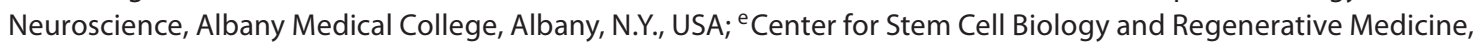 \\ School of Medicine, and ${ }^{\mathrm{f} T s i n g h u a-P e k i n g ~ C e n t e r ~ f o r ~ L i f e ~ S c i e n c e s, ~ T s i n g h u a ~ U n i v e r s i t y, ~ B e i j i n g, ~ C h i n a ~}$
}

\section{Key Words}

Cell lineage $\cdot$ Cortical development $\cdot$ Fate mapping .

Helix-loop-helix transcription factors · Preplate

\begin{abstract}
Mammalian cortical neurogenesis occurs on a precise time schedule during development. The earliest born neurons form the preplate and later separate into layer 1, which includes Cajal-Retzius (C-R) neurons, and the subplate. The preplate and its derivatives play a critical role in regulating subsequent neuron migration and cortical lamination. Using an early B cell factor 2 (Ebf2)-enhanced green fluorescent protein (EGFP) transgenic mouse line, we show that Ebf2EGFP is expressed in the preplate and persists in C-R neurons, allowing us to follow the development of these early born neurons. Therefore, Ebf2 is a genetic marker for preplate neurons from the earliest stage of their differentiation and $\mathrm{C}-\mathrm{R}$ cells after the preplate is split. Additionally, we examined the function of Ebf2 in the development of C-R neurons using both lentiviral-mediated knock-down overexpression approaches to perturb Ebf2 expression. Our data show that Ebf2 overexpression increases the generation of early born neurons including C-R cells, while Ebf 2 knock-down decreases it, without affecting the generation of other layer-specific
\end{abstract}

neurons in vitro. These results indicate that Ebf2 is important for early cortical neurogenesis and regulates the generation of C-R neurons in the developing cerebral cortex.

Copyright $\odot 2011$ S. Karger AG, Basel

\section{Introduction}

Neuroepithelial cells in the cortical ventricular zone (VZ) begin to produce neurons shortly after initial expansion through symmetric divisions. The first-born neurons are generated as early as embryonic day (E) 10 in mice and form the preplate, which is located above the $\mathrm{VZ}$ and beneath the pial surface $[1,2]$. The preplate is then split into the marginal zone (MZ; layer 1 ) and the subplate by immigrating cortical plate neurons that lay cortical layers in an inside-out manner (late-born neurons form the upper layers by traversing through the deeper layers) $[3,4]$. The MZ is the most superficial cortical layer containing Cajal-Retzius (C-R) cells, whereas the subplate neurons line the lower border of the cortical plate. Generation of these early born neurons marks the first dif-

\section{S.-M.C. and Y.W. contributed equally to this work.}

\section{KARGER}

Fax +41613061234 E-Mail karger@karger.ch www.karger.com (c) 2011 S. Karger AG, Basel

0378-5866/11/0336-0479\$38.00/0

Accessible online at:

www.karger.com/dne
Qin Shen

Center for Stem Cell Biology and Regenerative Medicine

School of Medicine, Tsinghua University

Beijing 100084 (China)

Tel. +86 106279 8087, E-Mail shenqin@ mail.tsinghua.edu.cn 
ferentiation step, which is accompanied by a transition in cortical neural progenitor cells; cortical neuroepithelial cells transform into radial glia and switch their division pattern from symmetric to asymmetric. Hence, understanding the molecular machinery controlling these early cortical neurogenic events would be important not only for insights into neuronal differentiation but also for neural progenitor progression. Yet, relatively little is known about the regulatory network involved in the specification and differentiation of these early born neurons.

C-R cells play a crucial role in regulating radial migration and lamination of cortical plate neurons and maintenance of radial glia, largely through their expression and secretion of the extracellular protein Reelin [5-8]. In reeler mice, which lack Reelin, cortical lamination is severely affected due to defects in the split of the preplate and neuronal migration. The ataxic gait of reeler mice is associated with a dramatic disruption of cell layering in laminated brain structures and severe hypoplasia of the cerebellum $[9,10]$. Fate mapping and cell lineage tracing studies have shown that $\mathrm{C}-\mathrm{R}$ cells arise from at least three specific locations along the pallial VZ, i.e. rostromedially from the pallial septum [also called retrobulbar area, commissural plate or medial pallial-subpallial boundary (PSB)], caudomedially from the cortical hem and laterally from the PSB (or the anti-hem region) [11-17]. These different origins give rise to distinct types of C-R cells that migrate tangentially to the cortical surface. For example, the cortical hem-derived C-R neurons, which express the transcription factor P73, primarily occupy the caudomedial and dorsolateral pallium [16], while the Dbx1-expressing cells at the septum produce C-R cells to populate the rostromedial pallium $[11,18]$. The PSB origin contributes to the C-R cells in the lateral and dorsolateral pallium, which expresses early B cell factor 2 (Ebf2), a member of the Ebf family of helix-loop-helix transcription factors [19-21].

The Ebf/Olf-1 gene family encodes a group of transcription factors (Ebf1-4) with a novel type of DNAbinding domain and a helix-loop-helix dimerization domain [19, 20, 22-25]. Ebf proteins were first identified in $\mathrm{B}$ lymphocytes and are required for B cell lineage differentiation [19]. We now know that they are involved in the development and function of many other cell types including adipocytes, osteoclasts and neuronal cells [26$30]$. In the central nervous system, Ebf2 is expressed in the first differentiating neurons migrating from the VZ along the spinal cord to the midbrain and at specific sites in the forebrain of mouse embryos [20, 29, 31-33]. Previ- ous studies have indicated that mutation of Ebf2 leads to a variety of nervous system defects, such as peripheral nerve abnormalities, migration defects of neurons that produce gonadotropin-releasing hormone, failed projections of olfactory neurons and abnormal development of cerebellar neurons $[28,29,33-35]$, indicating that Ebf2 is important for specific aspects of neuronal development. In the forebrain, in situ hybridization experiments from early studies show that Ebf2 is widely expressed in early postmitotic neurons in regions including the septum, hippocampus and neocortex [20].

Recently, Ebf2 was identified in a screen for C-R neuron-specific markers in the E13.5 brain [36] and used as a marker for ventral pallium-derived C-R neurons [37]. However, its expression during the earliest stage of cortical neurogenesis when the preplate has just been formed and its function in C-R neuron generation is not clear. Here, using a transgenic mouse line generated by the Gene Expression Nervous System Atlas (GENSAT) Project which reveals Ebf2-expressing cells with the enhanced green fluorescent protein (EGFP) reporter, our study provides new insight into the molecular pathway regulating early neurogenesis in the developing cerebral cortex.

\section{Materials and Methods}

\section{Animals}

A transgenic mouse line, $\mathrm{Tg}$ (Ebf2-EGFP)58Gsat/Mmcd, created by the GENSAT Project using a modified bacterial artificial chromosome (BAC) [38], was obtained from the NIH Mutant Mouse Regional Resource Center, and a colony of mice was established in the animal facility of the Neural Stem Cell Institute. The transgene contains the coding sequence for EGFP, followed by a polyadenylation signal, inserted into the mouse genomic BAC [38] RP24-283N8 at the ATG transcription initiation codon of the Ebf2 genes, where the expression of the reporter $\mathrm{mRNA}$ /protein is driven by the regulatory sequences of the mouse gene [39]. Timed pregnant mice were generated by crossbreeding hemizygote males with wild-type Swiss Webster females. Genotypes were examined by PCR analysis of DNA extracted from tail samples taken at the time of weaning following recommended Mutant Mouse Regional Resource Center protocols. Embryos were selected by direct visualization of the EGFP signal, and genotypes were confirmed by PCR. This transgenic mouse line offers us a powerful tool to study the dynamic expression pattern of Ebf2 and the morphology of Ebf2expressing cells during cortical development, allowing us to identify Ebf2-expressing cells without using an antibody and to visualize this subset of cells in live preparations.

\section{Cortical Cell Culture}

For the adherent culture, cerebral cortices of mouse embryos (E10-E18) from timed pregnant Swiss Webster females (Taconic Farms) or the Ebf2-BAC-EGFP mouse embryos were dissected and dissociated as described previously and cultured in serum- 
free DMEM with $10 \mathrm{ng} / \mathrm{ml}$ fibroblast growth factor-2 (Invitrogen) in poly-L-lysine-coated Terasaki plates [40-42]. For clonal analysis, single cells were plated at a density of 10-20 cells/well (E11), $40-60$ cells/well (E14) or 60-80 cells/well (E16) in Terasaki microwell plates. Clonal development was monitored daily by microscopic inspection. For neurosphere cultures, single dissociated cortical cells were cultured in serum-free DMEM with $20 \mathrm{ng} / \mathrm{ml}$ fibroblast growth factor- 2 and $20 \mathrm{ng} / \mathrm{ml}$ epidermal growth factor (both from Invitrogen) in ultra-low-binding 6-well plates (Costar/Corning) for 7 days in vitro. For passaging, neurospheres were collected and dissociated using papain (Worthington) for 20 min at $37^{\circ} \mathrm{C}$ with gentle trituration. Single cells were replated at equal density for each condition, and the number of neurospheres generated was counted after 7 days in vitro.

For transfection experiments, cortical progenitors were plated as adherent cultures in 6-well plates in the media conditions listed above. Twelve hours after plating, cells were transfected with either an empty vector control (H1), Ebf2 short hairpin RNA (shRNA) or Ebf2 overexpression plasmids using Stemfect 2.0 (Stemgent). Twelve micrograms of plasmid and $2 \mu$ l of Stemfect were used per well. Fifteen random fields per condition were imaged and counted in each experiment.

\section{Immunohistochemistry and Immunocytochemistry}

Ebf2-EGFP mouse embryos of different embryonic ages (E10E18) were dissected out and fixed in $4 \%$ paraformaldhyde in PBS for 4-12 $\mathrm{h}$ depending on the age. Cryostat sections and cell cultures were fixed and immunostained as described previously [42]. The primary antibodies we used were as follows: mouse IgG2b anti- $\beta$ tubulin III for neuronal cells (Sigma; 1:600); rabbit IgG anti-Ki67 for dividing cells (Labvision; 1:200); mouse monoclonal anti-Reelin (Chemicon; 1:400); rabbit anti-Tbrl (Millipore; 1:100); rabbit polyclonal anti-Foxp2 (E. Morrisey, University of Pennsylvania, Philadelphia, Pa., USA) and Tle4 (S. Stifani, McGill University, Montreal Que., Canada; 1:1,000). Immunoreactivity was visualized using Alexa Fluor-conjugated secondary antibodies (Molecular Probes; 1:1,000). Phase and fluorescent images were acquired using a Zeiss Z-1 apotome inverted microscope and a Zeiss AxioCam MRm digital camera with Axiovision 4.6 software.

\section{Time-Lapse Video Recording}

Time-lapse video microscopy was used to determine whether cortical progenitor cells produce Ebf2-EGFP ${ }^{+}$cells in culture. The clonal cultures were placed onto the heated, motorized stage inside a Pecon XLSI incubation chamber with heat, temperature and $\mathrm{CO}_{2}$ control modules. The time-lapse microscopy system consisted of a Zeiss Observer Z1 inverted epifluorescence microscope, a heated and motorized stage, a Colibri high-performance LED fluorescence light source, an HXP 120 UV light source and an Orca low-heat digital camera. From our experience, all C-R neurons in culture are born within 5 days. After culture and recording for 3-5 days, the plates were fixed and stained for Reelin and $\beta$-tubulin III to confirm the identity of C-R neurons. The time-lapse image series was analyzed and the lineage trees were reconstructed as described previously [42].

Lentiviral Vector Production and Viral Packaging

At least 3 shRNA hairpins, specifically targeted to the Ebf2 gene [5'-untranslated region (UTR), 3'-UTR and the open reading frame (ORF) region], were designed using the Dharmacon
siDESIGN Center program (see www.dharmacon.com for design site). shRNA and overexpression constructs for the Ebf2 sequence (accession number NM_010095.3) were constructed, harvested and titered as described previously [42-44]. Oligonucleotides containing a 19-mer sequence targeting either the ORF, $5^{\prime}$-UTR or 3'-UTR, followed by a loop sequence and then reverse complement, were synthesized and cloned into the $\mathrm{H} 1$ lentiviral vector using XbaI/SmaI. The 3 shRNA sequences are as follows: (1) the top full sequence for Ebf2 ORF shRNA is 5'-GTACTCACTACAAGTTACATTCAAGAGATGTAACTTGTAGTGAGTACTTTTTTGT-3', and the bottom full sequence for Ebf2 ORF shRNA is 5'-CTAGACAAAAAAGTACTCACTACAAGTTACATCTCTTGAATGTAACTTGTAGTGAGTAC-3'; (2) the top full sequence for Ebf2 5'-UTR shRNA is 5'-GCGCAGATCAGAATACAAATTCAAGAGATTTGTATTCTGATCTGCGCTTTTTTGT-3', and the bottom full sequence for Ebf2 5'-UTR shRNA is 5'-CTAGACAAAAAAGCGCAGATCAGAATACAAATCTCTTGAATTTGTATTCTGATCTGCGC-3', and (3) the top full sequence for Ebf2 3'-UTR shRNA is 5'-CCATAGAACTTTGGAGAAATTCAAGAGATTTCTCCAAAGTTCTATGGTTTTTTGT-3', and the bottom full sequence for Ebf2 3'-UTR shRNA is 5'-CTAGACAAAAAACCATAGAACTTTGGAGAAATCTCTTGAATTTCTCCAAAGTTCTAGG-3'. For overexpression constructs, the ORF of Ebf2 was obtained from Open Biosystems and was PCR-amplified, sequence-verified and cloned into a modified version of FUGW. An internal ribosomal entry site-EGFP was also included to mark the cells. For viral transduction, lentiviral vectors were added to cortical cultures just before plating at a multiplicity of infection of 10 .

\section{Semiquantitative PCR and Real-Time Quantitative PCR}

Total RNA was extracted from viral-transduced cells using Trizol reagent (Invitrogen) and treated with DNase I. cDNA was prepared with SuperScript III (Invitrogen) and used as a template for PCR. The website used for primer design was BLAST (http:// blast.ncbi.nlm.nih.gov/Blast.cgi).

The following primers were used for PCR amplification:

5'-TGCCATCCCGATTTCATATT-3' and 5'-GCTCCTCTCATCCCAACAAG-3' for Ebf2, and 5'-TCCCACTCTTCCACCTTCGATGC-3' and 5'-GGGTCTGGGATGGAAATTGTGAG-3' for GAPDH. All expression values were normalized against GAPDH. All amplifications were performed in triplicate.

For real-time quantitative PCR, PCR core reagents and SYBR green (ABI) were used with 200-nM forward and reverse primers. Real-time quantitative PCR was performed with the ABI PRISM 7700 Sequence Detection System. A standard curve was generated for each primer pair, and genes of interest were assigned a relative expression value interpolated from this standard curve using the threshold cycle according to ABI's instructions. All expression values were normalized against GAPDH. All amplifications were performed in triplicate.

\section{Western Blots}

Protein concentration was calculated using the bicinchoninic acid assay. Equal amounts of protein $(30 \mu \mathrm{g} / \mathrm{lane})$ were loaded into $12 \%$ Invitrogen NuPAGE Novex BisTris gels and transferred onto nitrocellulose membranes. Membranes were blocked with $5 \%$ milk for $2 \mathrm{~h}$ at room temperature and blotted overnight at $4^{\circ} \mathrm{C}$ with the following antibodies: Ebf2 (Sigma; 1:1,000), lamin A/C (Cell Signaling Technology; 1:1,000) and actin (Upstate Signal- 

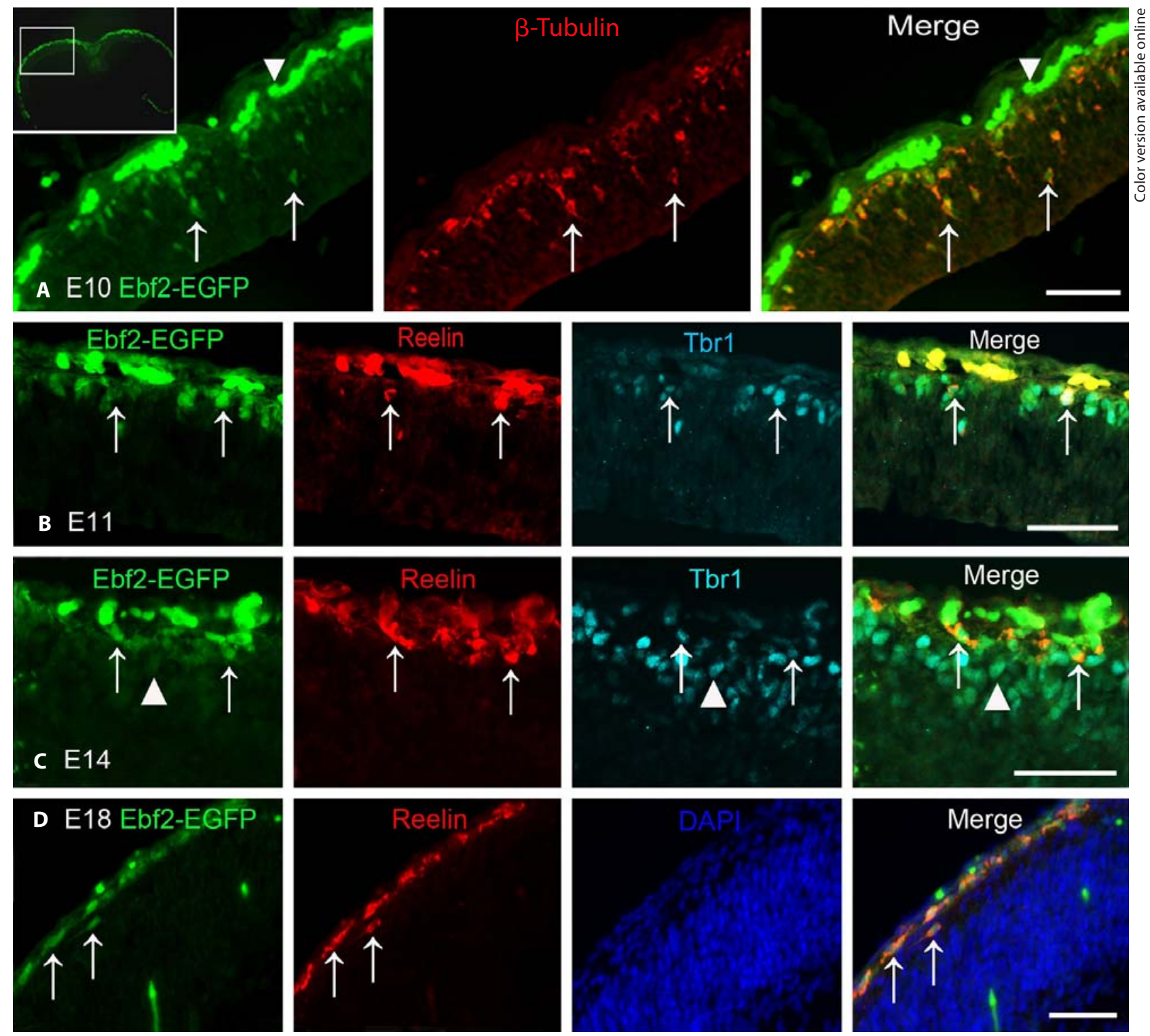

Fig. 1. Ebf2 marks the early differentiating neurons in the preplate of the developing cerebral cortex. A Ebf2-EGFP expression in E10 forebrain sections (boxed area in the inset). Ebf2-EGFP was expressed in a thin layer underneath the pial surface. Ebf2-EGFP ${ }^{+}$ cells (arrows) were seen migrating from the VZ towards the pial surface and were colabeled with $\beta$-tubulin III staining. Note that all $\beta$-tubulin III $^{+}$cells express Ebf2-EGFP at this stage. We also observed a bright signal in blood cells (arrowheads) in the overlying meninges. B At E11, all Ebf2-EGFP-expressing neurons were positive for a preplate marker Tbr1, but only a few Ebf2-EGFP ${ }^{+}$ neurons started to express Reelin (arrows). C At E14, a layer of cells showing strong Ebf2-EGFP expression underneath the pial surface were Reelin ${ }^{+}$(arrows), and below this layer cells showing weak EGFP expression were Reelin ${ }^{-} \mathrm{Tbrl}^{+}$(arrowheads). D Ebf2EGFP expression was retained in Reelin ${ }^{+}$cells in layer 1 at E18. Scale bar $=50 \mu \mathrm{m}$. E Quantitative analysis of the percentage of cells that were positive for Ebf2-EGFP and layer-specific markers in E11 and E14 cortical sections ( $n=6 ; 40-50$ cells per section).

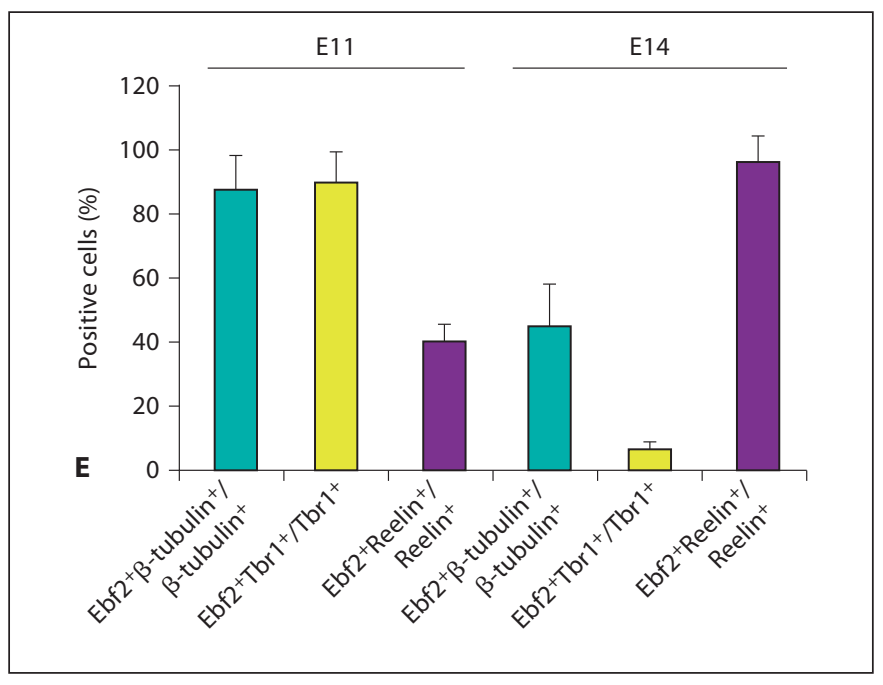


ing; 1:5,000). Peroxidase-conjugated secondary antibodies (Jackson ImmunoResearch) were used at 1:10,000 for $1 \mathrm{~h}$ at room temperature. ECL (Pierce) was the chemical substrate, and blots were developed with Kodak film. One-way ANOVA was used to identify experimental groups that were significantly different from control groups, with a Bonferroni correction for multiple comparisons ( $p$ value 0.05 ).

\section{Statistics}

All statistical tests, $\mathrm{t}$ tests and one-way ANOVAs with Bonferroni post hoc tests were performed with Statistica version 7.0.

\section{Results}

Ebf2-EGFP BAC Transgenic Mice Show Specific EGFP Expression in Preplate Neurons during Early Embryonic Cortical Development

The preplate and its derivatives in the MZ and the subplate play an important role in cortical organization. However, it remains a challenge to specifically identify preplate neurons using cellular and molecular markers. Markers such as Tbrl and the Golli transgene are expressed in the preplate and in cells of both the MZ and subplate, but also appear in deep-layer cortical neurons at later stages $[45,46]$. We screened the GENSAT Project Database (http://www.gensat.org) and identified the Ebf2 transgenic BAC mouse line, which expresses an EGFP reporter in Ebf2-expressing cells and shows a specific expression profile during cortical development. To investigate the expression pattern of Ebf2 during cortical neurogenesis in more detail, we examined the Ebf2-EGFP transgenic embryos from E10 to E18 using brain sections and fluorescent microscopy (fig. 1; online suppl. fig. 1, www.karger.com/doi/10.1159/000330582). Strong EGFP signals were seen in the forebrain, midbrain and entire spinal cord of the live E10 embryo (online suppl. fig. 1A), which is consistent with the previously reported expression of Ebf2 in these sites [20]. On brain sections, we observed a bright green signal in the overlying meninges (fig. 1A, arrowheads) in addition to Ebf2-EGFP ${ }^{+}$cells in the primordial cortex. We were able to distinguish these cells from neural cells by their location and round morphology, and they were not included in our analysis. At E10-E11, we found that the Ebf2-EGFP expression appeared on the surface of the developing cortex in the superficial layer directly underneath the meninges, likely the preplate which was being formed above the proliferating cortical neuroepithelium (fig. 1A, B; online suppl. fig. 1B, C). Ebf2-EGFP-expressing cells were not detected in the $\mathrm{VZ}$ area lining the lateral ventricle, suggesting that Ebf2 is not expressed in dividing cortical progenitor cells.
Indeed, nearly all the Ebf2-EGFP ${ }^{+}$expression was colabeled with $\beta$-tubulin III staining (the early neuronal differentiation marker), indicating that Ebf2-EGFP ${ }^{+}$cells are early differentiating neurons (fig. 1A). We also observed that Ebf2-EGFP ${ }^{+}$cells were radially oriented, appearing to be migrating from the VZ to the pial surface (fig. 1A, arrows), suggesting that Ebf2 is turned on in young postmitotic neurons as they leave the cortical VZ. At E11, most Ebf2-EGFP ${ }^{+}$neurons were found to express $\mathrm{Tbrl}^{+}(95 \pm 5 \% ; \mathrm{n}=6)$, which is a marker for preplate neurons at this stage [45], but only a few started to express Reelin (40 $\pm 6.5 \%$; fig. $1 \mathrm{~B}$, E). These findings indicate that the onset of Ebf 2 expression coincided with first neuronal differentiation, and Ebf2-EGFP ${ }^{+}$cells are generated from cortical neuroepithelial cells and make up the preplate. Hence, this transgenic mouse line provides a unique tool to study the very early steps of neurogenesis.

\section{Ebf2-EGFP $P^{+}$Expression Persists in C-R Cells during Embryonic Cortical Development}

As cortical development proceeds, the preplate is split into the MZ (layer 1), where C-R cells reside, and the subplate [4]. We found that strong expression of Ebf2-EGFP ${ }^{+}$ persists in C-R cells, identified by Reelin staining, in layer 1 after the preplate splits, while the intensity of the Ebf2-EGFP signal in the subplate, identified by Tbr1 staining, became much weaker, although still detectable. At E14, most Ebf2-EGFP ${ }^{+}$cells underneath the pial surface had acquired Reelin expression (fig. 1C, arrows), but below the Ebf2-EGFP ${ }^{+}$Reelin ${ }^{+}$layer, the weak Ebf2expressing cells remained Reelin ${ }^{-} \mathrm{Tbrl}^{+}$(fig. 1C, arrowheads). By E18, almost all Ebf2-EGFP ${ }^{+}$cells were located in layer 1 and were Reelin ${ }^{+}$(fig. 1D, arrows). The Ebf2EGFP transgenic line also showed a strong EGFP signal in C-R cells at the PSB, in the neocortex and in medial regions (online suppl. fig. $1 \mathrm{~B}, \mathrm{C}$ ), including the cortical hem, in which Ebf2-EGFP overlapped with P73 expression (online suppl. fig. 1D). Hence, this transgenic line can be used as a pan-C-R neuron reporter line. These results indicate that Ebf2 is expressed in the earliest born neurons before Reelin expression at the beginning of cortical neurogenesis and is continuously expressed in C-R cells in layer 1. Therefore, Ebf2 is a specific marker for $\mathrm{C}-\mathrm{R}$ cells from the onset to the end of neurogenesis in the developing cerebral cortex.

Ebf2-EGFP Expression in Cortical Cell Culture Reflects Developmental Progression of Cortical Progenitor Cells

Our previous study showed that cortical progenitor cells are capable of generating different layer-specific 

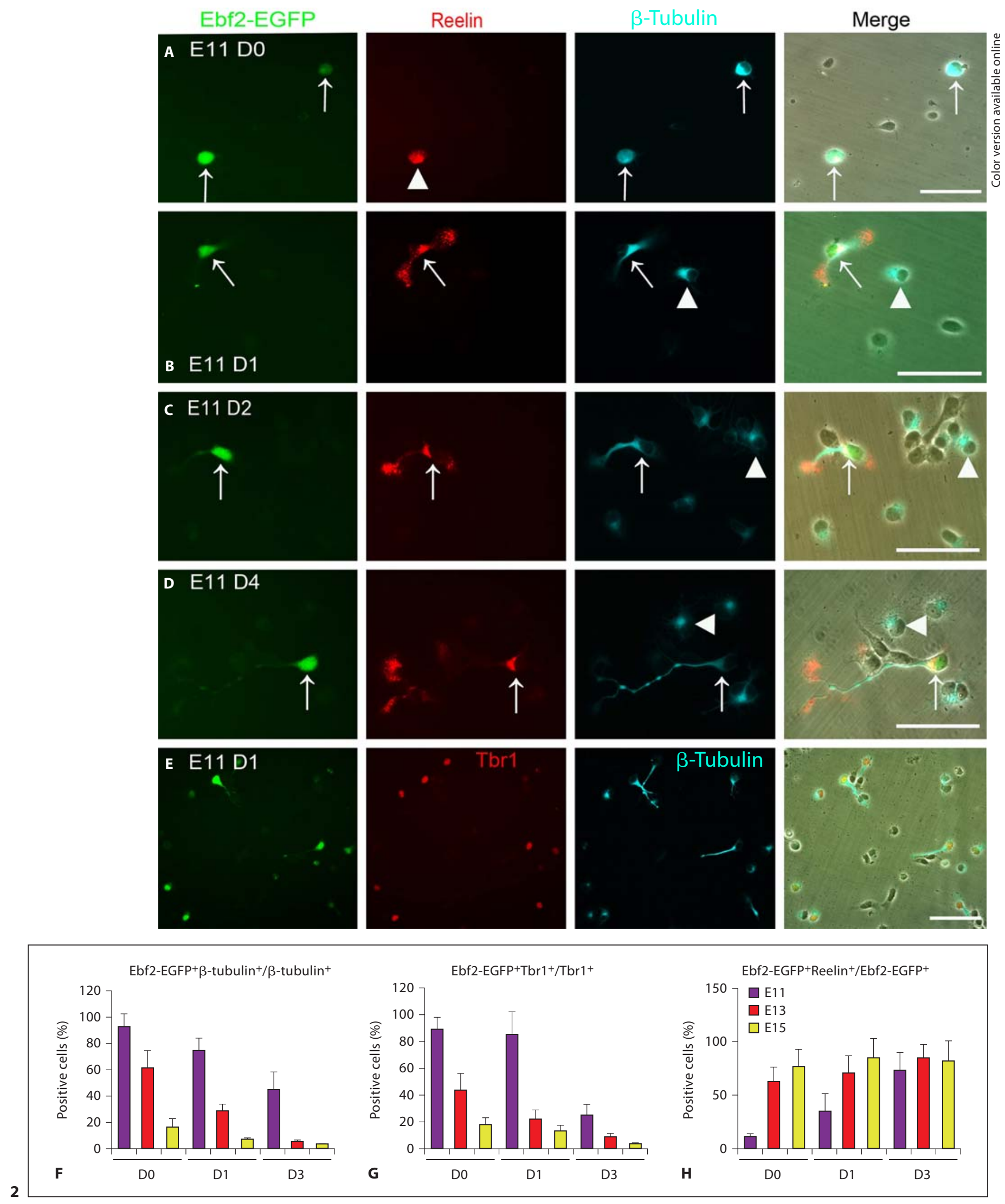
neuronal subtypes in vitro in the same time order as they do in vivo [42]. Given the restricted expression of Ebf2EGFP in preplate neurons, including C-R cells, we hypothesized that the BAC-EGFP transgenic line would allow us to directly assess the development of early differentiating neurons in cell culture. We examined Ebf2EGFP expression in acutely isolated cortical cells at different stages from E11 to E18. The cerebral cortices of Ebf2-EGFP transgenic mouse embryos were dissected and dissociated into single cells, and Ebf2-EGFP expression in acutely isolated cells and in clonal culture was evaluated. We found that EGFP expression was retained after dissociation and fixation, and although it was weak in culture, the EGFP signal was detectable without additional EGFP staining (fig. 2). In acutely dissociated single cells at E11, almost all $\beta$-tubulin $\mathrm{III}^{+}$cells were Ebf2 ${ }^{+}$ (fig. 2A, F). As the cells developed in culture, Ebf2-EGFP ${ }^{+}$ cells were always $\beta$-tubulin $\mathrm{III}^{+}$(fig. $2 \mathrm{~B}-\mathrm{D}$, arrows), but some $\beta$-tubulin $\mathrm{III}^{+}$cells did not express Ebf2-EGFP (fig. 2B-D, arrowheads), indicating that Ebf2-EGFP labels a subpopulation of early differentiating neurons in culture. We found that the percentage of Ebf2-EGFP cells in neurons ( $\beta$-tubulin $\mathrm{III}^{+}$cells) in E11 cortical cell culture decreased dramatically from day (D) 0 (acute) to D3 (3 days in culture; fig. $2 \mathrm{~F}$ ), and at D3, only $2.5 \pm 0.5 \%$ of neurons were $\mathrm{Ebf} 2$ - $\mathrm{EGFP}^{+} \beta$-tubulin $\mathrm{III}^{+}$, indicating that Ebf2-EGFP is expressed in early born neurons and that later progenitor cells no longer make $\mathrm{Ebf}^{+}$cells (fig. 2). Similarly, we found that the percentage of Ebf2$\mathrm{EGFP}^{+}$cells in cortical cells was decreased as E11 cortical progenitor cells developed in culture (from $22 \%$ at D1 to

Fig. 2. Cortical progenitor cells from the early stage are capable of producing Ebf2-EGFP ${ }^{+}$cells, while late progenitor cells at E15 cannot. In E11 cortical cells, Ebf2-EGFP expression was colabeled with $\beta$-tubulin III and Reelin. A In acutely isolated E11 cortical cells, Ebf2-EGFP ${ }^{+}$cells were always $\beta$-tubulin $\mathrm{III}^{+}$(arrows) and some started to express Reelin (arrowhead). B-D As the cells grew in culture, Ebf2-EGFP ${ }^{+} \beta$-tubulin $\mathrm{III}^{+}$cells maintained Reelin expression, showing the characteristic morphology of C-R cells (arrows). Note that more $\beta$-tubulin $\mathrm{III}^{+}$cells (arrowheads) were negative for Ebf2-EGFP over time, indicating that later born neurons do not express Ebf2. E Nearly all Ebf2-EGFP ${ }^{+}$cells were colabeled with Tbr1 at D1. Scale bar $=50 \mu \mathrm{m}$. F-H Quantitative analyses of the developmental profile of Ebf2-EGFP-expressing cells doublelabeled with other markers in culture. The percentage of $\beta$-tubulin $\mathrm{III}^{+}$or $\mathrm{Tbrl}^{+}$cells that were Ebf2-EGFP ${ }^{+}$decreased with age and culture time $(\mathbf{F}, \mathbf{G})$, while Ebf2-EGFP expression appeared earlier than Reelin in cortical cell culture and Ebf2-EGFP ${ }^{+}$cells retained Reelin expression over time $(\mathbf{H})$.

Ebf2, Cortical Neurogenesis and Cajal-Retzius Neurons less than 2\% at D6; online suppl. fig. 2). Double staining with neuronal subtype markers showed that after 1 day (D1) in E11 culture, $40 \pm 9 \%$ of Ebf2-EGFP ${ }^{+}$cells were Reelin $^{+}$neurons (fig. $2 \mathrm{~B}, \mathrm{H}$ ), indicating that Ebf2-EGFP expression appears earlier than that of Reelin in cortical cell culture and marks additional early differentiating neurons that were not identified by Reelin expression in our previous study [42]. These early Ebf2-EGFP ${ }^{+}$neurons are likely preplate neurons, which can be labeled by Tbr1 [45]. Indeed, we found that in E11 cortical cell culture, almost all Tbrl ${ }^{+}$cells $(90 \pm 8 \%$ on D0, $85 \pm 15 \%$ on D1) were labeled for Ebf2-EGFP (fig. 2E, G), but very few were positive for the deeper cortical layer markers Tle4 or Foxp2 (fig. 3C, D). By D3 of E11 culture, most Ebf2-EGFP cells ( $80 \pm 12 \%$; fig. $2 \mathrm{H})$ became Reelin ${ }^{+}$, and in some cases they showed the characteristic morphology of C-R cells with puncta of Reelin expression at the endings of processes (fig. 2B-D). These results show that the timing and pattern of Ebf2-EGFP expression in cortical culture is consistent with the in vivo finding that Ebf2 is first expressed in preplate neurons and then persists in C-R cells.

\section{Ebf2 Is Not Expressed in Other Layer-Specific Neurons} from Cortical Progenitor Cells

To confirm whether the expression of Ebf2 is restricted in preplate neurons and C-R cells in vivo, we examined coronal sections of Ebf2-EGFP-expressing embryos from midgestation to the late embryonic stage when cortical plate neurons are generated. Using the antibody Foxp2 to label subplate and layer 6 neurons and Tle4 to label cortical deep layers, we showed that Ebf2-EGFP ${ }^{+}$cells were essentially not colabeled with Foxp2 staining and Tle4 staining, confirming that Ebf2 was not expressed in other cortical layers in vivo (fig. 2A, B).

To further confirm that Ebf2-EGFP expression defined the preplate neurons in vitro, we stained primary culture cells derived from the forebrain cortex of E11 Ebf2-EGFP ${ }^{+}$embryos. Quantitative analyses of the percentage of Ebf2-EGFP ${ }^{+}$or layer-specific marker-positive cells and total $\beta$-tubulin $\mathrm{III}^{+}$cells in E11 cortical culture cells are shown in figure $3 \mathrm{E}$ and $\mathrm{F}$. Our results revealed that in E11 primary cell culture, approximately 73\% $( \pm 9 \%)$ of Ebf2-EGFP ${ }^{+}$cells were colabeled with $\beta$-tubulin, and $22 \%( \pm 8.2 \%)$ of $\beta$-tubulin ${ }^{+}$cells were Reelin ${ }^{+}$, $83 \%( \pm 9.3 \%)$ were $\mathrm{Tbr}^{+}, 7 \%( \pm 1.0 \%)$ were Foxp2 $2^{+}$and $13 \%( \pm 2.2 \%)$ were Tle $4^{+}$(fig. 3E). Double labeling with Tle4 or Foxp2 showed rare overlap with Ebf2-EGFP expression, excluding the possibility that Ebf2-EGFP ${ }^{+}$cells were cortical plate neurons (fig. 3C-F). These results im- 
Ebf2-EGFP
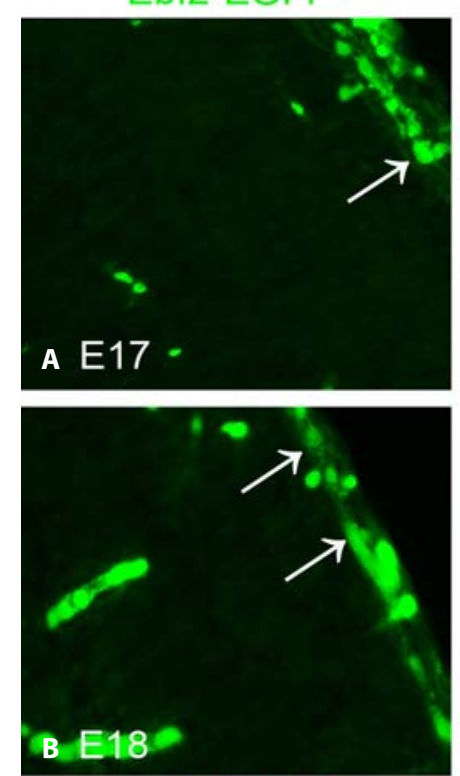

Ebf2-EGFP

c E11 D1

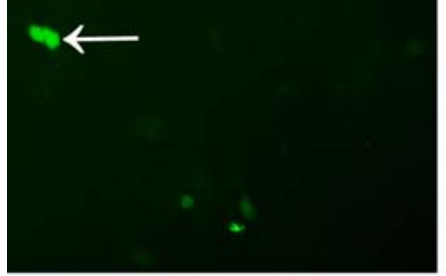

D E11 D1

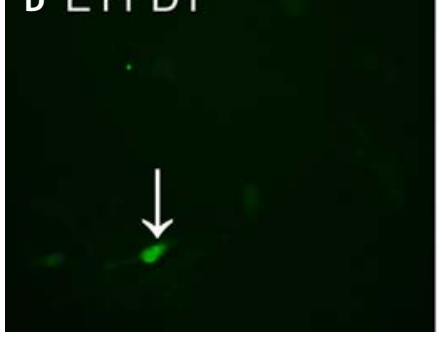

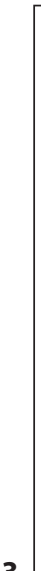

3

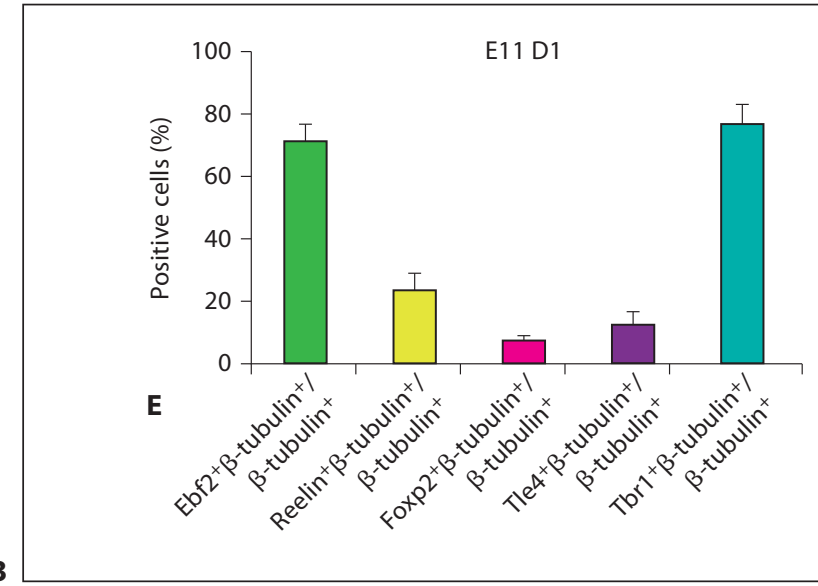

E
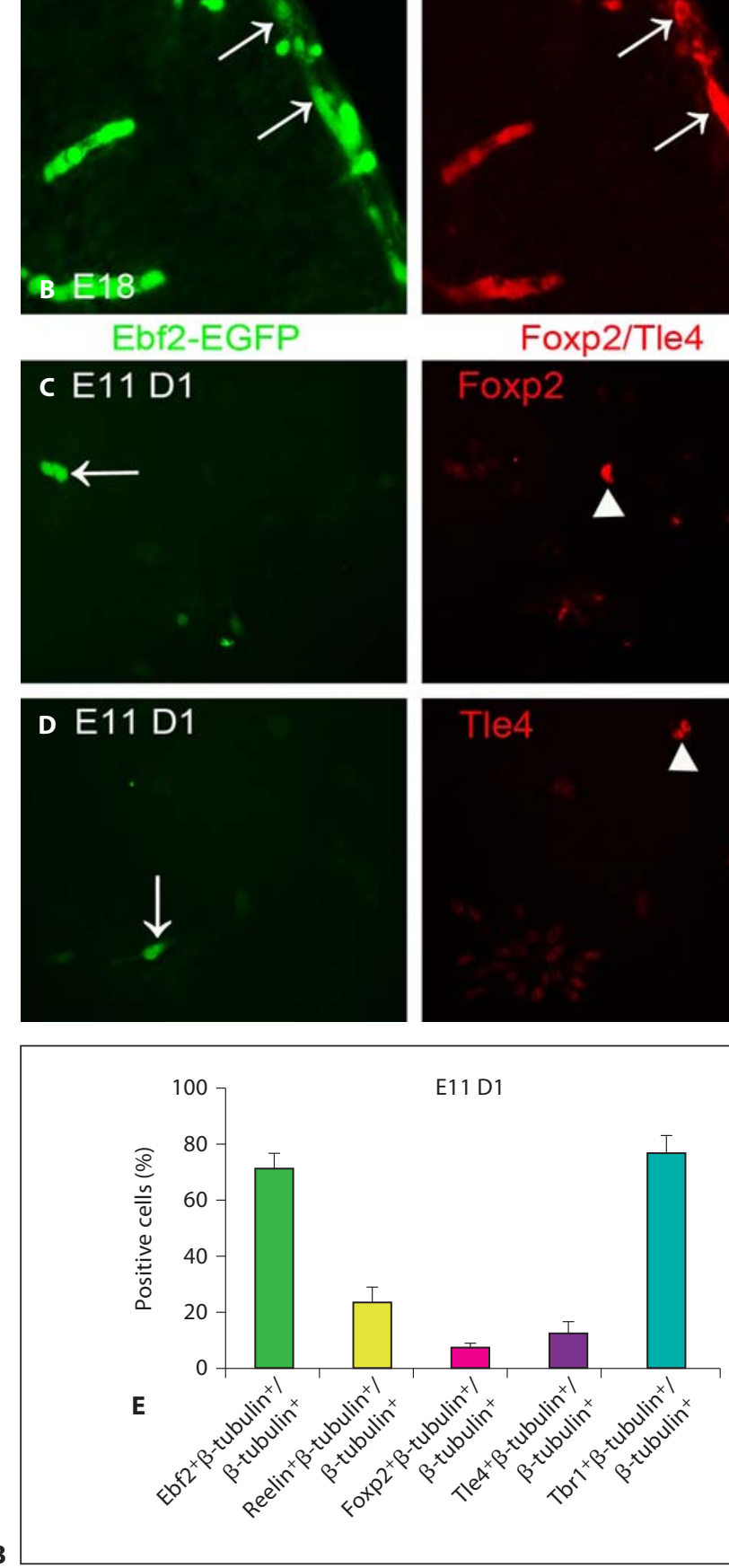

Foxp2/Tle4
Foxp2/Tle4
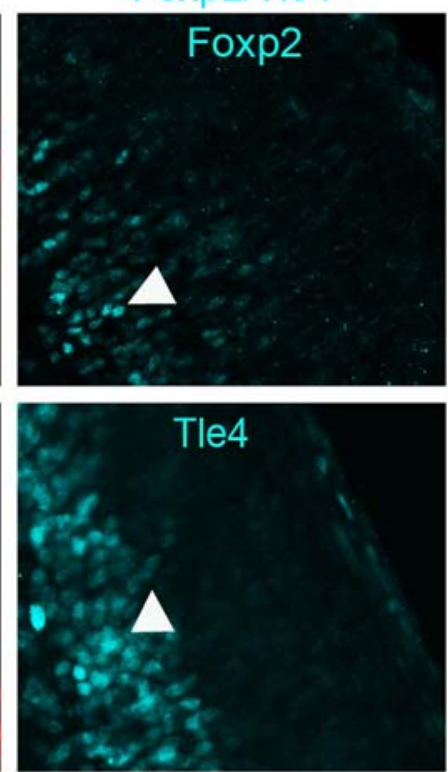

B-Tubulin
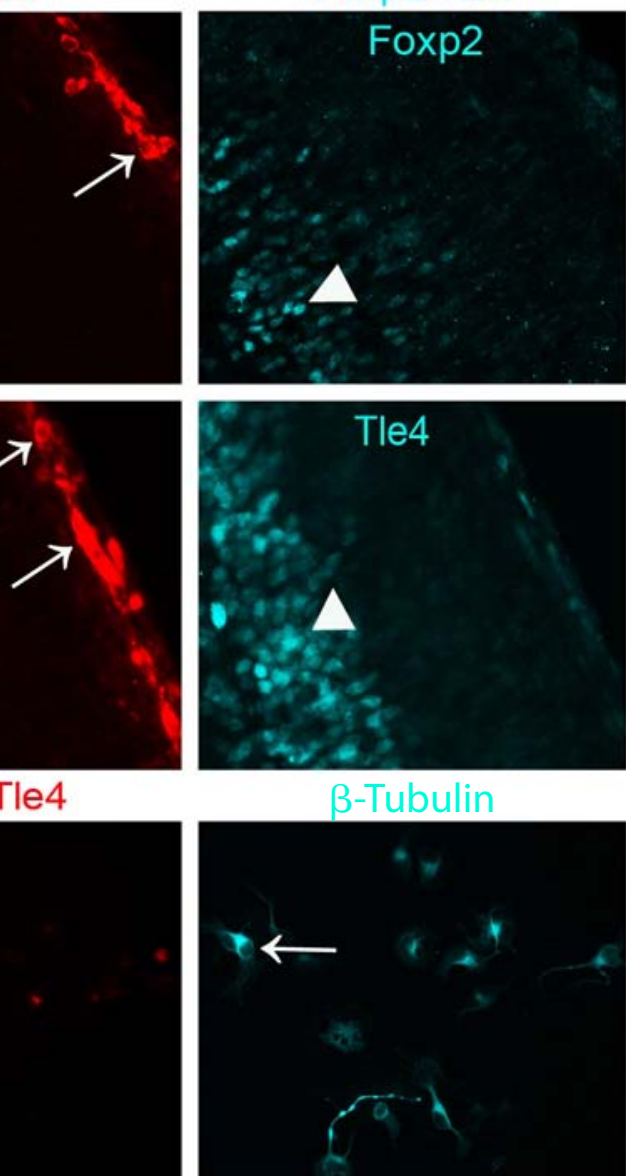
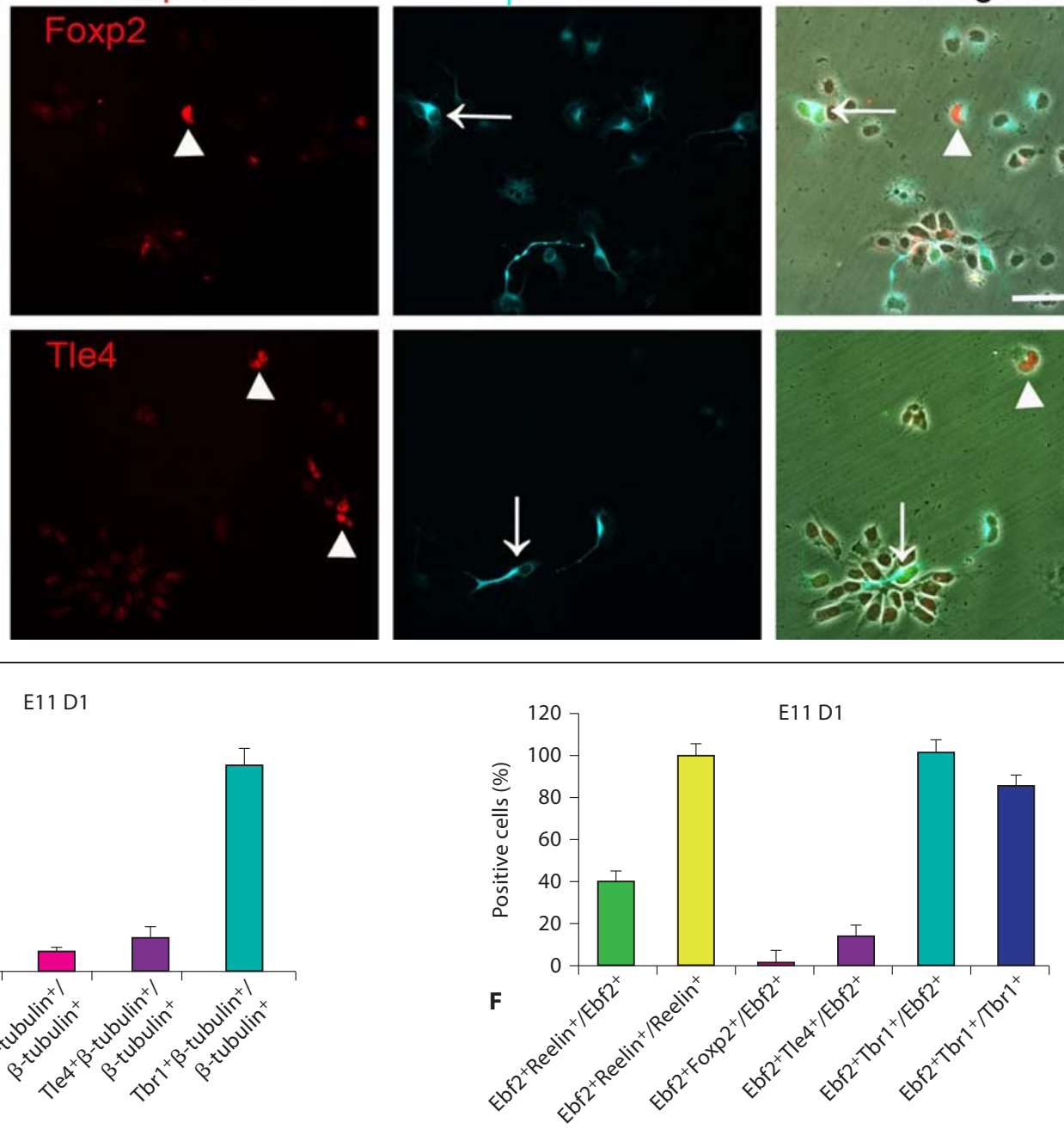

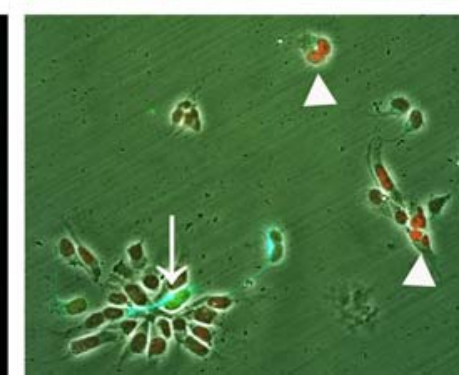

Merge

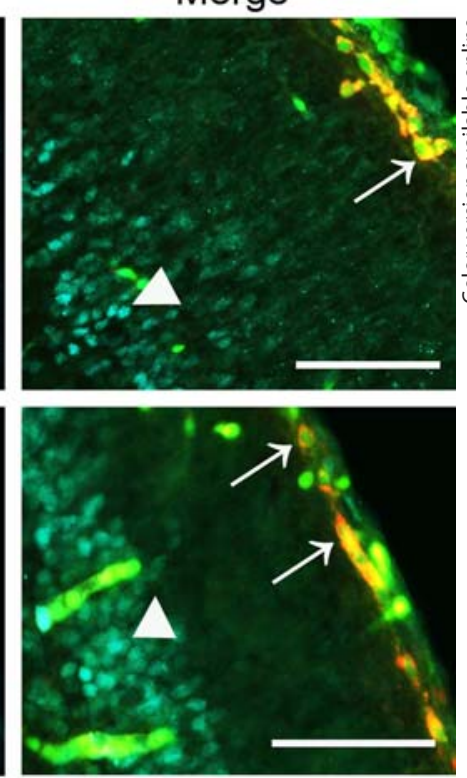

Merge

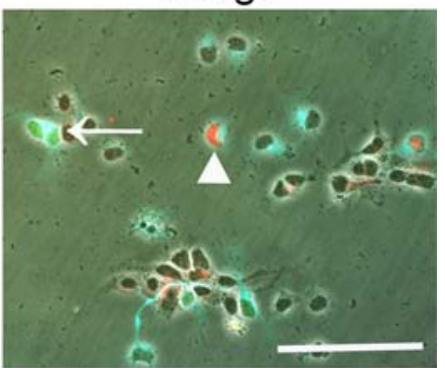

11 D1 
ply that Ebf2 is specifically expressed in Reelin ${ }^{+} \mathrm{C}-\mathrm{R}$ cells but not in other layer-specific neurons in vivo.

\section{Late Cortical Progenitor Cells Lose the Ability to} Generate Ebf2-EGFP ${ }^{+}$Cells

We also found that late cortical progenitor cells (E15) lost the ability to generate Ebf2-EGFP ${ }^{+}$cells (online suppl. fig. 2). Similarly, results of experiments using nonadherent culture conditions in which cortical neural stem cells form floating neurospheres showed that E11 neurospheres produced Ebf2-EGFP ${ }^{+}$neurons, while E18 neurospheres did not (fig. 4), confirming our previous finding that the potential of cortical neural stem cells is restricted during development [42]. Therefore, Ebf2-EGFP expression reflects the timing of production of early born neurons, including Reelin ${ }^{-}$preplate neurons, and provides a direct measure of the intrinsic capability of cortical progenitors to produce early born neurons.

\section{Neural Progenitor Cells from Ebf2-EGFP Transgenic}

Mice Divide Asymmetrically and Generated Ebf2-

$E_{G F P}{ }^{+} C-R$ Neurons at the Earliest Cell Division

We further examined the lineage development of E10.5 cortical progenitor cells derived from Ebf2-EGFP transgenic mice using fluorescent time-lapse video microscopy. Ebf2-EGFP expression usually appeared right after the first division of E10.5 cortical progenitor cells. Lineage reconstruction showed that Ebf2-EGFP neurons were always generated at the first or second round of divisions (fig. 5). The live imaging series from a single cell to the final stained clone from which lineage tree $G$ was generated is shown in figure $5 \mathrm{~B}$. Using $\beta$-tubulin III and Reelin staining to mark C-R neurons, we found that Ebf2EGFP-expressing cells were colabeled with $\beta$-tubulin III and Reelin (fig. 5C). These findings indicate that E10-E11 individual cortical progenitor cells divide asymmetrically and generate Ebf2-EGFP ${ }^{+}$Reelin $^{+} \mathrm{C}-\mathrm{R}$ neurons at the earliest cell division.

Fig. 3. Ebf2 is expressed in preplate neurons but not in cortical plate neurons. A, B The Ebf2-EGFP-expressing cells were Reelin ${ }^{+}$ in the MZ (arrows) but were not Foxp $2^{+}$(A, arrowheads) or Tle $4^{+}$ (B, arrowheads) in the cortical plate. C, D Ebf2-EGFP ${ }^{+}$cells (arrows) were not colabeled with Foxp2 (C, arrowheads) or Tle4 (D, arrowheads) in culture. Scale bar $=50 \mu \mathrm{m}$. E, F Quantitative analysis of the percentage of layer-specific and Ebf2-positive cells was performed. It was found that almost all Ebf2-EGFP ${ }^{+}$cells were colabeled with $\beta$-tubulin III, but few were positive for the deeper cortical layer markers Tle4 or Foxp2.

Ebf2, Cortical Neurogenesis and

Cajal-Retzius Neurons

\section{Ebf2 Is Functionally Important in the Generation of}

\section{Reelin ${ }^{+}$Neurons}

To determine the function of Ebf2 in cortical early neuronal differentiation, we used Ebf2 shRNA and Ebf2overexpressing lentivirus to acutely knock down and overexpress Ebf2, respectively, in E11 cortical cell culture (fig. 6). Three shRNAs were designed to target either the Ebf2 ORF, 5'-UTR or 3'-UTR for efficient knock-down. Expression of Ebf2 in cortical cells after lentiviral transduction was first determined using semiquantitative PCR (fig. 6A) and Western blot (online suppl. fig. 3). We also made a scrambled shRNA construct, and comparison with an empty vector (H1) showed no difference in cell behavior, so the $\mathrm{H} 1$ construct was used as control in subsequent experiments. Compared to control lentivirus (H1), Ebf2 mRNA was reduced by more than $45 \%$ after Ebf2 shRNA transduction with the 5'-UTR and 3'-UTR constructs in cortical cells. Using real-time quantitative PCR, we further confirmed that the 3'-UTR Ebf2 shRNA construct reduced the Ebf2 mRNA level by $56.2 \pm 8.7 \%$, and thus it was chosen for subsequent analysis. In contrast, Ebf 2 mRNA expression was increased by more than $500 \%$ with the Ebf2-overexpressing lentiviral vector, as compared to control lentivirus, indicating the efficiency of the constructs (fig. 6A). Similarly, the protein level of Ebf2 was reduced by shRNA constructs and augmented by the overexpression construct, as detected by Western blot (online suppl. fig. 3).

We then examined the effect of altering the expression of Ebf2 in adherent E11 cortical cultures. The cells were fixed after 3-6 days in culture and then immunostained for Ki67, the neuronal marker $\beta$-tubulin III and the C-R cell marker Reelin. The percentages of positive cells in Ebf2 shRNA-treated and Ebf2-overexpressed groups were compared with the control group (fig. 6B-F). We found that perturbing the Ebf2 level did not affect the percentage of $\mathrm{Ki} 67^{+}$cells (fig. 6B; online suppl. fig. 4) and $\beta$-tubulin $\mathrm{III}^{+}$cells (fig. $6 \mathrm{~B}$; suppl. fig. $5 \mathrm{~A}-\mathrm{C}$ ) in culture compared to the control, indicating that Ebf2 is not required for cell proliferation and total neuronal production (fig. 6B). However, we found that the percentage of both $\mathrm{Tbrl}^{+}$and Reelin ${ }^{+}$neurons in adherent E11 cortical cultures was reduced in the Ebf2 shRNA-treated group but increased in the Ebf 2 overexpression group compared with the control (fig. 6C-F; online suppl. fig. 5D-F). These findings demonstrate that Ebf2 function is not required for progenitor cell proliferation and subsequent neuronal differentiation but is a key factor required for the generation of specific early born neurons, including Reelin ${ }^{+} \mathrm{C}-\mathrm{R}$ neurons. 

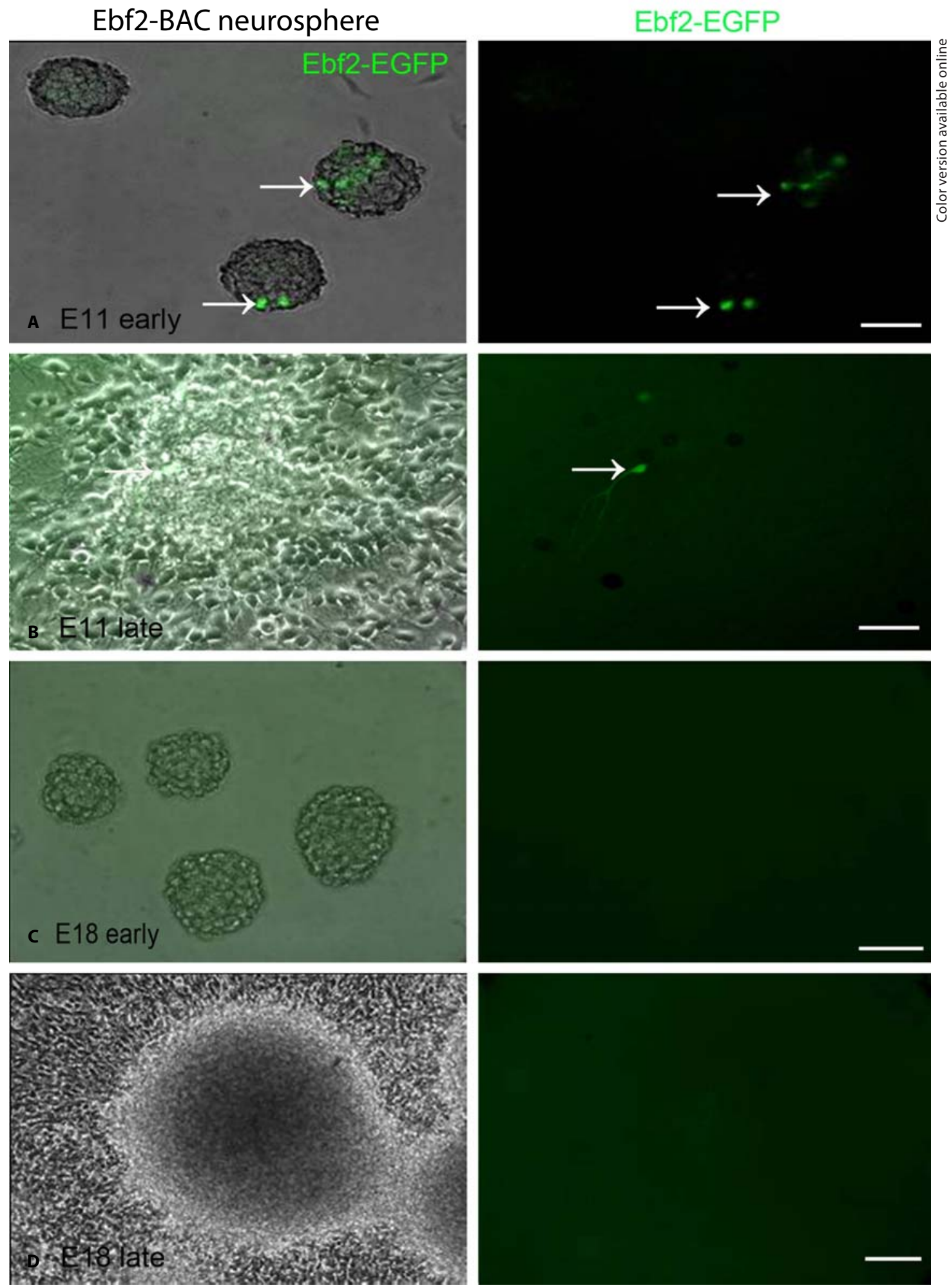

Fig. 4. Cortical progenitor cells are restricted in their ability to generate Ebf2-EGFP ${ }^{+}$cells during development. Cortical progenitor cells from VZ and subventricular zone (SVZ) regions of E11 and E18 cerebral cortex form floating neurospheres in nonadherent culture. We found that E11 neurospheres produced Ebf2-
$\mathrm{EGFP}^{+}$neurons (arrows), while E18 neurospheres did not. A, C Live imaging microscopy showing Ebf2-EGFP ${ }^{+}$cells in the neurospheres. B, D The neurospheres cultured were in a condition of differentiation. Scale bar $=50 \mu \mathrm{m}$. 

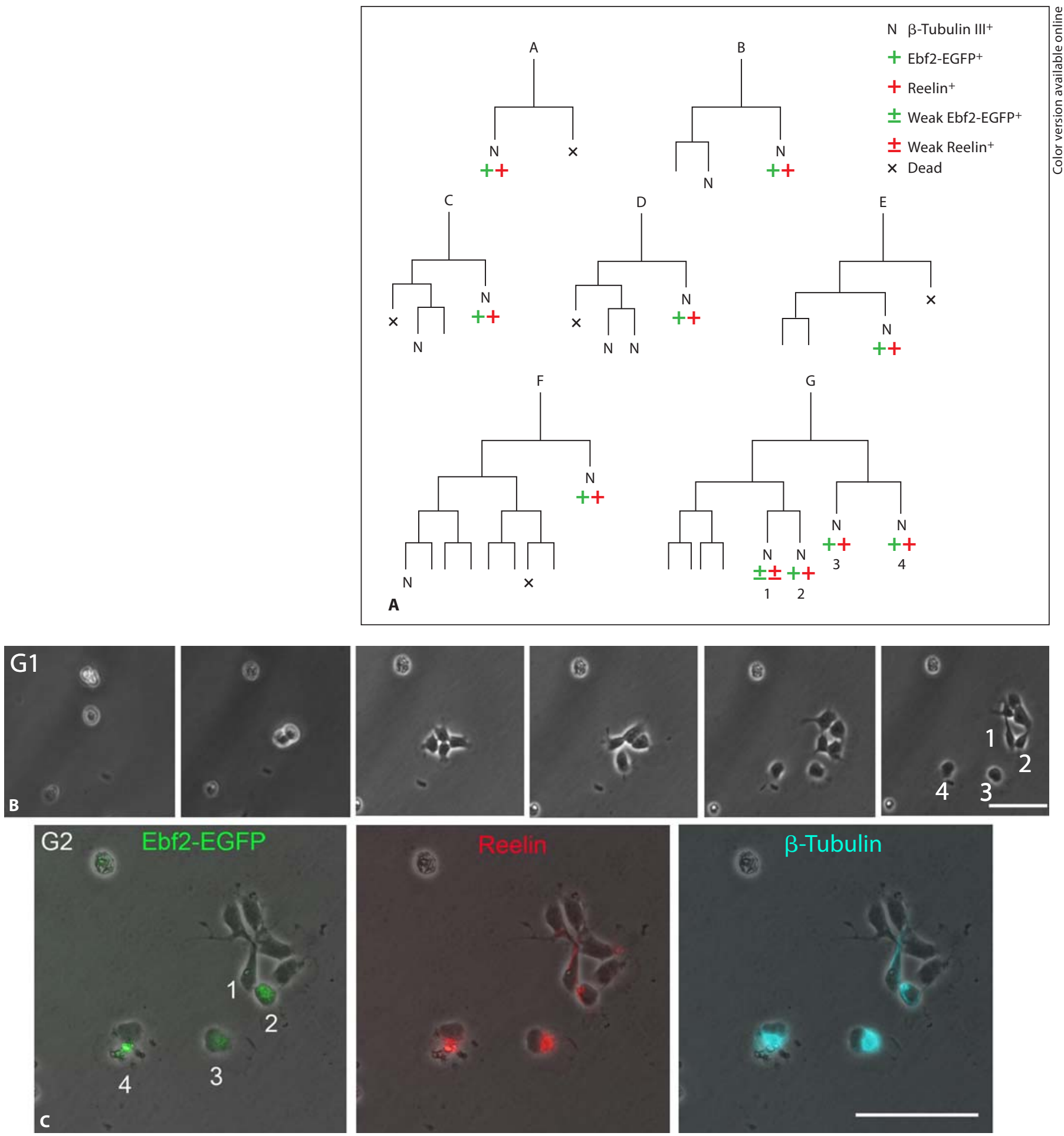

Fig. 5. Neural progenitor cells from the Ebf2-BAC-EGFP transgenic mice divide asymmetrically and generate $\mathrm{Ebf} 2-\mathrm{EGFP}^{+} \mathrm{C}-\mathrm{R}$ cells at early divisions. A Representative lineage trees of single E10.5 cortical progenitor cells reconstructed from long-term time-lapse recordings of clonal growth for 3 days in vitro. The clones were fixed at the end of recording and stained for Reelin and $\beta$-tubulin III. Ebf2-EGFP was directly visualized. Cortical progenitor cells including stem cells and neuroblasts generated Ebf2-EGFP ${ }^{+}$Reelin ${ }^{+} \mathrm{C}-\mathrm{R}$ neurons, which appeared at the earliest cell divisions. B, C The live imaging series from a single cell to the final stained clone from which lineage tree $G$ was generated. The numbers indicate corresponding cells in the images and in the lineage tree. Scale bar $=50 \mu \mathrm{m}$. 

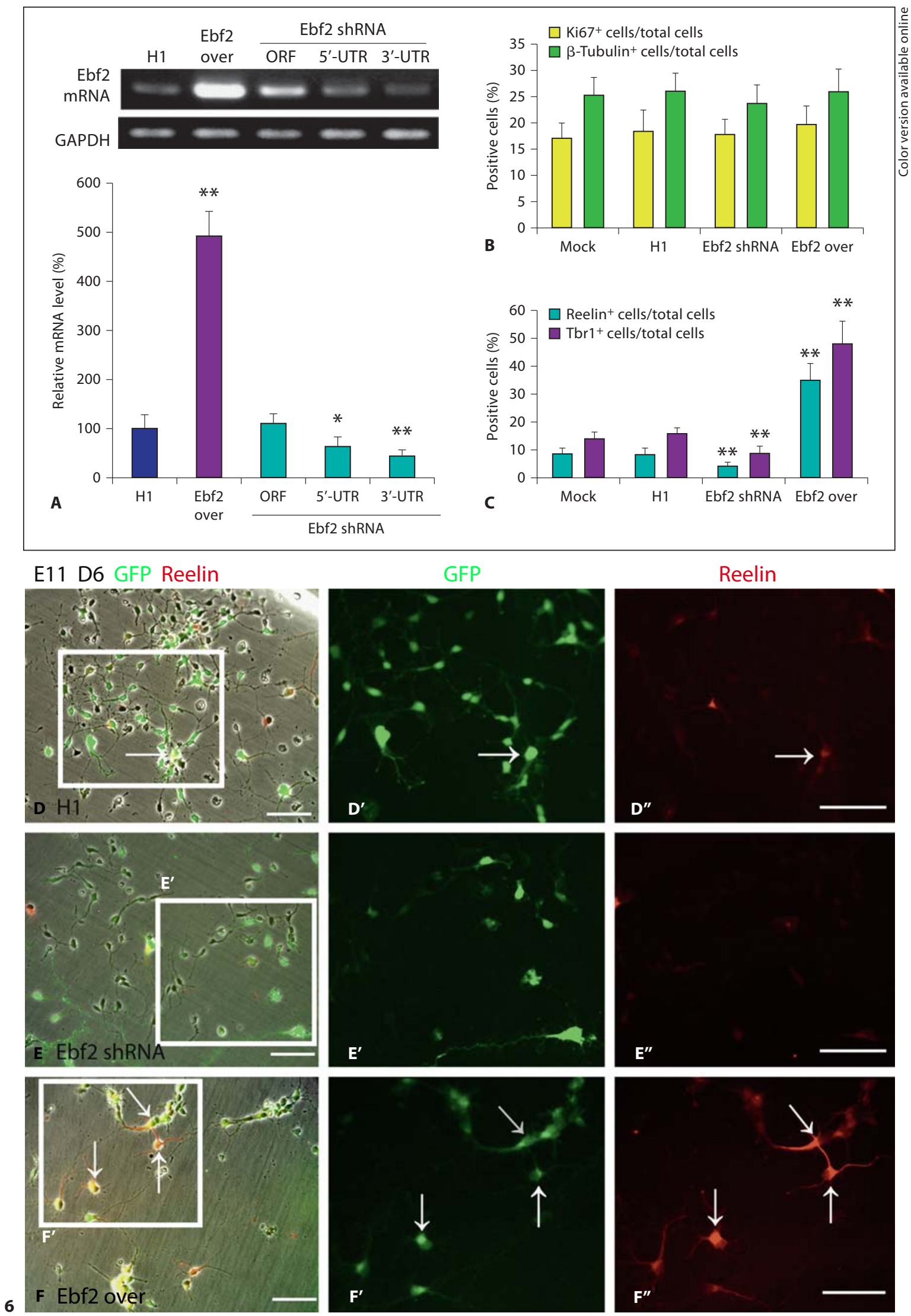


\section{Discussion}

In this study, we identify Ebf2 as an early marker for cortical neuronal differentiation which first marks preplate neurons, then persists in C-R neurons. Our results show that cortical neural progenitor cells produce preplate neurons, that contribute to the $\mathrm{C}-\mathrm{R}$ population in the MZ (layer 1), confirming that C-R cells also originate from the cortical neuroepithelium in addition to other non-pallial origins. We provide new insight into the molecular regulatory mechanism for early cortical neurogenesis.

The transgenic mouse lines generated by the GENSAT Project using BAC technology express reporter genes such as EGFP under the control of the native locus [39]. By using a large DNA transgene, the in vivo expression pattern of the endogenous gene can be reproduced more faithfully, and the reporter proteins can reveal more detailed cellular morphology $[39,47]$. Hence, the BAC transgenic mouse lines allow the design of in vivo approaches to analyze gene expression and function in developmental brain as well as isolation of a specific cell population for genetic analysis [47]. The Ebf2-BAC transgenic mouse line we identified allowed us to directly monitor the dynamic developmental behavior of Ebf2-EGFP ${ }^{+}$cells in vitro and to visualize Ebf2-EGFP ${ }^{+}$cells in vivo when a suitable antibody for immunodetection of Ebf2 in the brain is not available. We

Fig. 6. Perturbation of Ebf2 expression in cortical progenitor cells affects the generation of $C$ - $R$ cells without changing total neuronal production and proliferation. A Ebf 2 mRNA level after shRNA or overexpression (Ebf2 over) treatment compared with empty vector (H1) in E11 cortical cell culture analyzed by semiquantitative PCR and real-time quantitative PCR. Expression levels were normalized for GAPDH ( $n=6$ experiments). ${ }^{*} \mathrm{p}<0.05,{ }^{* *} \mathrm{p}<0.01$ versus $\mathrm{H} 1$ control. B Quantification of the percentage of $\mathrm{Ki}^{+} 7^{+}$and $\beta$ tubulin $\mathrm{III}^{+}$cells after Ebf2 shRNA knock-down and overexpression (Ebf2 over) ( $\mathrm{n}=6$ experiments). Mock: without lentiviral transduction. We found that perturbing the Ebf2 level did not affect the percentage of $\mathrm{Ki}^{+} 7^{+}$cells and $\beta$-tubulin $\mathrm{III}^{+}$cells in culture compared to control, indicating that Ebf 2 is not required for cell proliferation and total neuronal production. C Alteration of Ebf2 level affects production of $\mathrm{Tbrl}^{+}$and Reelin ${ }^{+}$neurons. Quantification of Reelin ${ }^{+}$and Tbrl $^{+}$cells after Ebf2 shRNA knock-down and overexpression (Ebf2 over) shows that the percentages of Tbrl ${ }^{+}$and Reelin $^{+}$cells were reduced by Ebf 2 shRNA treatment and increased by Ebf2 overexpression in cortical cell culture $(n=6$ experiments). ${ }^{* *} \mathrm{p}<0.01$ versus $\mathrm{H} 1$ control. D-F Examples of E11 cortical cells transduced with Ebf2 shRNA, Ebf2 overexpression constructs or the control H1 lentivirus (indicated by EGFP) that were stained for Reelin [54]. Arrows indicate some Reelin ${ }^{+}$cells. Scale bar $=50 \mu \mathrm{m}$

Ebf2, Cortical Neurogenesis and Cajal-Retzius Neurons showed that the Ebf2-EGFP transgene labeled the earliest born neurons, which form the preplate and its derivatives, particularly C-R cells in the developing forebrain. Its expression is excluded from neurons in other cortical layers. Recently, a study of the same transgenic line reported that Ebf2-EGFP expression is retained in C-R cells in the postnatal brain [48]. Hence, the Ebf2-BAC-EGFP transgenic mouse line provides a unique tool to study early born neurons throughout their development.

Recently, Ebf2 was identified in a screen for C-R neuron markers and its expression was considered to be restricted to the ventral pallium during midgestation as detected by in situ hybridization [37]. In our study, we found that the expression of Ebf2-EGFP is widely distributed in early differentiating neurons in the telencephalon, from the most medial area to the ventral lateral pallial region (online suppl. fig. 1) throughout the embryonic stages. It is possible that the expression of Ebf2 is precisely regulated at different stages and that repression of Ebf 2 in the dorsomedial region occurs as development proceeds. The Ebf2-BAC-EGFP construct could be resistant to such regulation, as it maintained Ebf2 expression throughout development. The stability of EGFP could also lead to prolonged detection of positive cells which no longer express Ebf2. However, our data are consistent with the in situ hybridization results reported by Garel et al. [20], which showed stronger expression of Ebf2 in medial regions such as the septum and hippocampus at E13. Further confirmation of the expression pattern of Ebf2 awaits suitable antibodies for immunohistochemistry. Nevertheless, the restricted expression of Ebf2-EGFP defines a specific population of cells that form the preplate and its derivatives and allows further characterization of these cells in vivo and purification in vitro. Along with other BAC transgenic lines that show specific expression in early born neurons, such as the $\operatorname{Tg}(\operatorname{Lrp12} / \mathrm{Mig} 13 \mathrm{a}-\mathrm{Egfp})$ line and the $\operatorname{Tg}$ (Pde1C-EGFP) line [49, 50], this transgenic line serves as a useful tool to study early cortical neurogenesis.

We noticed that Ebf2-EGFP expression remains in subplate neurons after the preplate is split, although it is much weaker than that in layer 1 (fig. 1). This expression of Ebf2 in subplate neurons has not been reported before. As the GENSAT transgenic mouse line may not always accurately reflect expression of the endogenous gene, we do not know whether this additional expression pattern is real. It is possible that the stable EGFP protein accumulated in the preplate cells and then persisted into the subplate neurons. Although we think this is unlikely because we still observed weak subplate expression of Ebf2-EGFP at E18, a destabilized EGFP construct would reflect the 
precise temporal change in gene expression pattern [51]. Interestingly, the Ebf2-EGFP expression pattern is similar to that of the Pde1C-EGFP transgenic line in that the EGFP persists in C-R cells and is downregulated in subplate neurons, whereas Lrp12/Mig13a-EGFP is maintained in subplate neurons but downregulated in C-R cells during cortical development. Comparison of gene expression profiles of purified EGFP-expressing cells derived from these lines would provide putative markers that differentially label these early born neurons and shed light on the regulatory machinery engaged in preplate differentiation and later separation of $\mathrm{C}-\mathrm{R}$ neurons and subplate neurons.

The recent discovery of multiple origins of C-R cells from noncortical areas raises the question of whether any C-R cells are generated within the cerebral cortex. Our previous clonal and lineage analysis indicated that cortical progenitor cells are capable of generating both Reelin ${ }^{+}$ cells and cortical plate neurons [42], and other evidence also suggests that $\mathrm{C}-\mathrm{R}$ cells are locally generated within the neocortical area and are derived from the pallial expressed transcription factor Emx1 lineage $[2,52,53]$. We showed that Ebf2-EGFP-expressing cells are located just above the proliferating zone, migrate radially toward the pial surface, express Reelin in layer 1 and become Reelin ${ }^{+}$ $\mathrm{C}-\mathrm{R}$ neurons in layer 1 . The fact that cerebral cortex-derived Ebf2 ${ }^{+}$cells are also $\mathrm{Tbrl}^{+}$and Reelin ${ }^{+}$in culture further supported the idea that cortical progenitor cells give rise to $\mathrm{C}-\mathrm{R}$ cells and that a common precursor for $\mathrm{C}-\mathrm{R}$ cells and the subplate neurons does exist. The Ebf2EGFP mouse line makes it possible to directly follow the trajectory of Ebf2-expressing cells in vivo in order to fully understand the onset, migration and connection of C-R cells during cortical development. For example, tracking of Ebf2-expressing cells in the postnatal brain has provided direct evidence of the ultimate fate of $\mathrm{C}-\mathrm{R}$ cells in the MZ [48].

In summary, our study has identified Ebf2 as a genetic marker for preplate neurons from the earliest stage and $\mathrm{C}-\mathrm{R}$ cells after the preplate is split. We also demonstrated that Ebf2 function is not required for progenitor cell proliferation and subsequent neuronal differentiation but is a key factor required for the generation of specific early born neurons including Reelin ${ }^{+} \mathrm{C}-\mathrm{R}$ neurons.

\section{Acknowledgments}

We are most grateful to Dr. Sally Temple for invaluable advice and discussion. We are also grateful for the financial support of the Regenerative Research Foundation and Neural Stem Cell Institute. We thank Dr. Morrisey and Dr. Stifani for gifts of antibodies, Gretchen Kusek, Patricia Lederman and Rachel Wurlster for animal care and other members of the New York Neural Stem Cell Institute for their help. We also thank the Department of Anatomy, College of Medicine and Division of Research Resource, Kaohsiung Medical University, Kaohsiung, Taiwan, ROC, for providing help to Shu-Mien Chuang.

\section{References}

$\checkmark 1$ Caviness VS Jr: Neocortical histogenesis in normal and reeler mice: a developmental study based upon $[3 \mathrm{H}]$ thymidine autoradiography. Brain Res 1982;256:293-302.

-2 Hevner RF, Neogi T, Englund C, Daza RA, Fink A: Cajal-Retzius cells in the mouse: transcription factors, neurotransmitters, and birthdays suggest a pallial origin. Brain Res Dev Brain Res 2003;141:39-53.

3 Bayer SA, Altman J: Neocortical Development. New York, Raven, 1991

4 Bystron I, Blakemore C, Rakic P: Development of the human cerebral cortex: Boulder Committee revisited. Nat Rev Neurosci 2008;9:110-122.

-5 D'Arcangelo G, Miao GG, Chen SC, Soares HD, Morgan JI, Curran T: A protein related to extracellular matrix proteins deleted in the mouse mutant reeler. Nature 1995;374: 719-723.

-6 Hirotsune S, Takahara T, Sasaki N, Hirose K, Yoshiki A, Ohashi T, Kusakabe M, Murakami Y, Muramatsu M, Watanabe S, et al: The reeler gene encodes a protein with an EGFlike motif expressed by pioneer neurons. Nat Genet 1995; 10:77-83.

7 Ogawa M, Miyata T, Nakajima K, Yagyu K, Seike M, Ikenaka K, Yamamoto H, Mikoshiba K: The reeler gene-associated antigen on Cajal-Retzius neurons is a crucial molecule for laminar organization of cortical neurons. Neuron 1995; 14:899-912.

8 Super H, Del Rio JA, Martinez A, Perez-Sust $P$, Soriano E: Disruption of neuronal migration and radial glia in the developing cerebral cortex following ablation of CajalRetzius cells. Cereb Cortex 2000;10:602613.

-9 Caviness VS Jr, Rakic P: Mechanisms of cortical development: a view from mutations in mice. Annu Rev Neurosci 1978;1:297-326.

10 Rakic P, Caviness VS Jr: Cortical development: view from neurological mutants two decades later. Neuron 1995;14:1101-1104.

-11 Bielle F, Griveau A, Narboux-Neme N, Vigneau S, Sigrist M, Arber S, Wassef M, Pie- rani A: Multiple origins of Cajal-Retzius cells at the borders of the developing pallium. Nat Neurosci 2005;8:1002-1012.

12 Garcia-Moreno F, Lopez-Mascaraque L, De Carlos JA: Origins and migratory routes of murine Cajal-Retzius cells. J Comp Neurol 2007;500:419-432.

13 Imayoshi I, Shimogori T, Ohtsuka T, Kageyama R: Hes genes and neurogenin regulate non-neural versus neural fate specification in the dorsal telencephalic midline. Development 2008; 135:2531-2541.

14 Monuki ES, Porter FD, Walsh CA: Patterning of the dorsal telencephalon and cerebral cortex by a roof plate-Lhx 2 pathway. Neuron 2001;32:591-604.

15 Takiguchi-Hayashi K, Sekiguchi M, Ashigaki S, Takamatsu M, Hasegawa H, Suzuki-Migishima R, Yokoyama M, Nakanishi S, Tanabe Y: Generation of reelin-positive marginal zone cells from the caudomedial wall of telencephalic vesicles. J Neurosci 2004;24: 2286-2295. 
- 16 Yoshida M, Assimacopoulos S, Jones KR, Grove EA: Massive loss of Cajal-Retzius cells does not disrupt neocortical layer order. Development 2006;133:537-545.

17 Zhao C, Guan W, Pleasure SJ: A transgenic marker mouse line labels Cajal-Retzius cells from the cortical hem and thalamocortical axons. Brain Res 2006;1077:48-53.

18 Griveau A, Borello U, Causeret F, Tissir F, Boggetto N, Karaz S, Pierani A: A novel role for Dbx1-derived Cajal-Retzius cells in early regionalization of the cerebral cortical neuroepithelium. PLoS Biol 2010;8:e1000440.

19 Hagman J, Belanger C, Travis A, Turck CW, Grosschedl R: Cloning and functional characterization of early B-cell factor, a regulator of lymphocyte-specific gene expression. Genes Dev 1993;7:760-773.

-20 Garel S, Marin F, Mattei MG, Vesque C, Vincent A, Charnay P: Family of Ebf/Olf-1-related genes potentially involved in neuronal differentiation and regional specification in the central nervous system. Dev Dyn 1997; 210:191-205.

21 Wang SS, Tsai RY, Reed RR: The characterization of the Olf-1/EBF-like HLH transcription factor family: implications in olfactory gene regulation and neuronal development. J Neurosci 1997;17:4149-4158.

22 Wang MM, Reed RR: Molecular cloning of the olfactory neuronal transcription factor Olf-1 by genetic selection in yeast. Nature 1993;364:121-126.

23 Hagman J, Gutch MJ, Lin H, Grosschedl R: Ebf contains a novel zinc coordination motif and multiple dimerization and transcriptional activation domains. EMBO J 1995; 14: 2907-2916.

24 Wang SS, Betz AG, Reed RR: Cloning of a novel Olf-1/EBF-like gene, O/E-4, by degenerate oligo-based direct selection. Mol Cell Neurosci 2002;20:404-414.

-25 Siponen MI, Wisniewska M, Lehtio L, Johansson I, Svensson L, Raszewski G, Nilsson L, Sigvardsson M, Berglund H: Structural determination of functional domains in early B-cell factor (EBF) family of transcription factors reveals similarities to Rel DNA-binding proteins and a novel dimerization motif. J Biol Chem 2010;285:25875-25879.

-26 Jimenez MA, Akerblad P, Sigvardsson M, Rosen ED: Critical role for Ebf1 and Ebf2 in the adipogenic transcriptional cascade. $\mathrm{Mol}$ Cell Biol 2007;27:743-757.

- 27 Kieslinger M, Folberth S, Dobreva G, Dorn T, Croci L, Erben R, Consalez GG, Grosschedl R: Ebf2 regulates osteoblast-dependent differentiation of osteoclasts. Dev Cell 2005;9:757-767.

28 Wang SS, Lewcock JW, Feinstein P, Mombaerts P, Reed RR: Genetic disruptions of O/ $\mathrm{E} 2$ and $\mathrm{O} / \mathrm{E} 3$ genes reveal involvement in olfactory receptor neuron projection. Development 2004;131:1377-1388.

-29 Croci L, Chung SH, Masserdotti G, Gianola S, Bizzoca A, Gennarini G, Corradi A, Rossi F, Hawkes R, Consalez GG: A key role for the $\mathrm{HLH}$ transcription factor EBF2COE2,O/E-3 in Purkinje neuron migration and cerebellar cortical topography. Development 2006;133: 2719-2729.

- 30 Jin K, Jiang H, Mo Z, Xiang M: Early B-cell factors are required for specifying multiple retinal cell types and subtypes from postmitotic precursors. J Neurosci 2010;30:1190211916.

31 Garcia-Dominguez M, Poquet C, Garel S, Charnay P: Ebf gene function is required for coupling neuronal differentiation and cell cycle exit. Development 2003;130:60136025.

32 Malgaretti N, Pozzoli O, Bosetti A, Corradi A, Ciarmatori S, Panigada M, Bianchi ME, Martinez S, Consalez GG: Mmot1, a new helix-loop-helix transcription factor gene displaying a sharp expression boundary in the embryonic mouse brain. J Biol Chem 1997; 272:17632-17639.

33 Corradi A, Croci L, Broccoli V, Zecchini S, Previtali S, Wurst W, Amadio S, Maggi R, Quattrini A, Consalez GG: Hypogonadotropic hypogonadism and peripheral neuropathy in Ebf2-null mice. Development 2003;130:401-410.

34 Chung SH, Marzban H, Croci L, Consalez GG, Hawkes R: Purkinje cell subtype specification in the cerebellar cortex: early B-cell factor 2 acts to repress the zebrin II-positive Purkinje cell phenotype. Neuroscience 2008; 153:721-732.

35 Chung SH, Sillitoe RV, Croci L, Badaloni A, Consalez G, Hawkes R: Purkinje cell phenotype restricts the distribution of unipolar brush cells. Neuroscience 2009;164:14961508.

36 Yamazaki H, Sekiguchi M, Takamatsu M, Tanabe Y, Nakanishi S: Distinct ontogenic and regional expressions of newly identified Cajal-Retzius cell-specific genes during neocorticogenesis. Proc Natl Acad Sci USA 2004;101:14509-14514.

37 Hanashima C, Fernandes M, Hebert JM, Fishell G: The role of Foxg1 and dorsal midline signaling in the generation of Cajal-Retzius subtypes. J Neurosci 2007;27:11103-11111.

38 Backman M, Machon O, Mygland L, van den Bout CJ, Zhong W, Taketo MM, Krauss S: Effects of canonical Wnt signaling on dorsoventral specification of the mouse telencephalon. Dev Biol 2005;279:155-168.

39 Gong S, Zheng C, Doughty ML, Losos K, Didkovsky N, Schambra UB, Nowak NJ, Joyner A, Leblanc G, Hatten ME, Heintz N: A gene expression atlas of the central nervous system based on bacterial artificial chromosomes. Nature 2003;425:917-925.

40 Qian X, Goderie SK, Shen Q, Stern JH, Temple S: Intrinsic programs of patterned cell lineages in isolated vertebrate CNS ventricular zone cells. Development 1998;125:31433152.

41 Shen Q, Zhong W, Jan YN, Temple S: Asymmetric Numb distribution is critical for asymmetric cell division of mouse cerebral cortical stem cells and neuroblasts. Development 2002;129:4843-4853.
-42 Shen Q, Wang Y, Dimos JT, Fasano CA, Phoenix TN, Lemischka IR, Ivanova NB, Stifani S, Morrisey EE, Temple S: The timing of cortical neurogenesis is encoded within lineages of individual progenitor cells. Nat Neurosci 2006;9:743-751.

43 Fasano CA, Dimos JT, Ivanova NB, Lowry N, Lemischka IR, Temple S: shRNA knockdown of Bmi-1 reveals a critical role for p21$\mathrm{Rb}$ pathway in NSC self-renewal during development. Cell Stem Cell 2007;1:87-99.

-44 Fasano CA, Phoenix TN, Kokovay E, Lowry N, Elkabetz Y, Dimos JT, Lemischka IR, Studer L, Temple S: Bmi-1 cooperates with Foxg1 to maintain neural stem cell self-renewal in the forebrain. Genes Dev 2009;23:561-574.

45 Hevner RF, Shi L, Justice N, Hsueh Y, Sheng M, Smiga S, Bulfone A, Goffinet AM, Campagnoni AT, Rubenstein JL: Tbrl regulates differentiation of the preplate and layer 6 . Neuron 2001;29:353-366.

46 Landry CF, Pribyl TM, Ellison JA, Givogri MI, Kampf K, Campagnoni CW, Campagnoni AT: Embryonic expression of the myelin basic protein gene: identification of a promoter region that targets transgene expression to pioneer neurons. J Neurosci 1998;18: 7315-7327.

47 Heintz N: Bac to the future: the use of bac transgenic mice for neuroscience research. Nat Rev Neurosci 2001;2:861-870.

48 Chowdhury TG, Jimenez JC, Bomar JM, Cruz-Martin A, Cantle JP, Portera-Cailliau C: Fate of Cajal-Retzius neurons in the postnatal mouse neocortex. Front Neuroanat 2010;4:10.

-49 Schneider S, Gulacsi A, Hatten ME: Lrp12/ Mig13a reveals changing patterns of preplate neuronal polarity during corticogenesis that are absent in reeler mutant mice. Cereb Cortex 2011;21:134-144.

50 Osheroff H, Hatten ME: Gene expression profiling of preplate neurons destined for the subplate: genes involved in transcription, axon extension, neurotransmitter regulation, steroid hormone signaling, and neuronal survival. Cereb Cortex 2009;19(suppl 1):i126-i134

51 Li X, Zhao X, Fang Y, Jiang X, Duong T, Fan C, Huang CC, Kain SR: Generation of destabilized green fluorescent protein as a transcription reporter. J Biol Chem 1998;273: 34970-34975.

52 Meyer G, Schaaps JP, Moreau L, Goffinet AM: Embryonic and early fetal development of the human neocortex. J Neurosci 2000;20: 1858-1868.

53 Gorski JA, Talley T, Qiu M, Puelles L, Rubenstein JL, Jones KR: Cortical excitatory neurons and glia, but not GABAergic neurons, are produced in the Emx1-expressing lineage. J Neurosci 2002;22:6309-6314.

-54 Redruello B, Louro B, Anjos L, Silva N, Greenwell RS, Canario AV, Power DM: CRTAC1 homolog proteins are conserved from cyanobacteria to man and secreted by the teleost fish pituitary gland. Gene 2010; 456:1-14. 